Author manuscript

\title{
Postcards from the edge: A critical reading of representations of the interior in Australian landscape architecture
}

\author{
Julian Bolleter
}

To cite this article: Julian Bolleter (2017) Postcards from the edge: A critical reading of representations of the interior in Australian landscape architecture, Journal of Landscape Architecture, 12:1, 74-85, DOI: 10.1080/18626033.2017.1301290

To link to this article: http://dx.doi.org/10.1080/18626033.2017.1301290

Published online: 10 Mar 2017. 


\section{Postcards from the edge: A critical reading of representations of the interior in Australian landscape architecture}

Julian Bolleter University of Western Australia

\section{Abstract}

The arid interior of Australia has been conceptualized as the site of a barren wasteland in need of 'improvement', a place of symbolic sacrifice by European-Australian culture to the archetypal interior, a powerful symbol of the 'other', and a source of Australian authenticity. Since 2001, a number of key public projects located in Australia's capital cities have sought to represent and refer to the landscape of the interior through landscape design. This paper explores two such projects for how the profession of landscape architecture has applied the narratives of the Australian interior. These projects openly reflect the fact that European-Australian culture remains typically estranged from the landscapes of Australia's interior-a situation that has implications for the way landscape architecture deals with the drying of Australia's fertile fringes and engages with indigenous culture.

\section{Australia / Australian interior / indigeneity / colonialism}

\section{Reinterpreting narratives of the Australian landscape}

The 'centripetal impetus' originally set in motion by ancient myths of a 'Great South Land' convinced Europeans from Aristotle in the third century $\mathrm{BC}$ onwards that something 'extraordinary' was to be found in Australia's interior (Gibson 1992: 10). Subsequently, Australia's interior was often regarded, by Eurocentric settlers in the nineteenth and early to midtwentieth centuries, as a bitter disappointment requiring 'improvement'

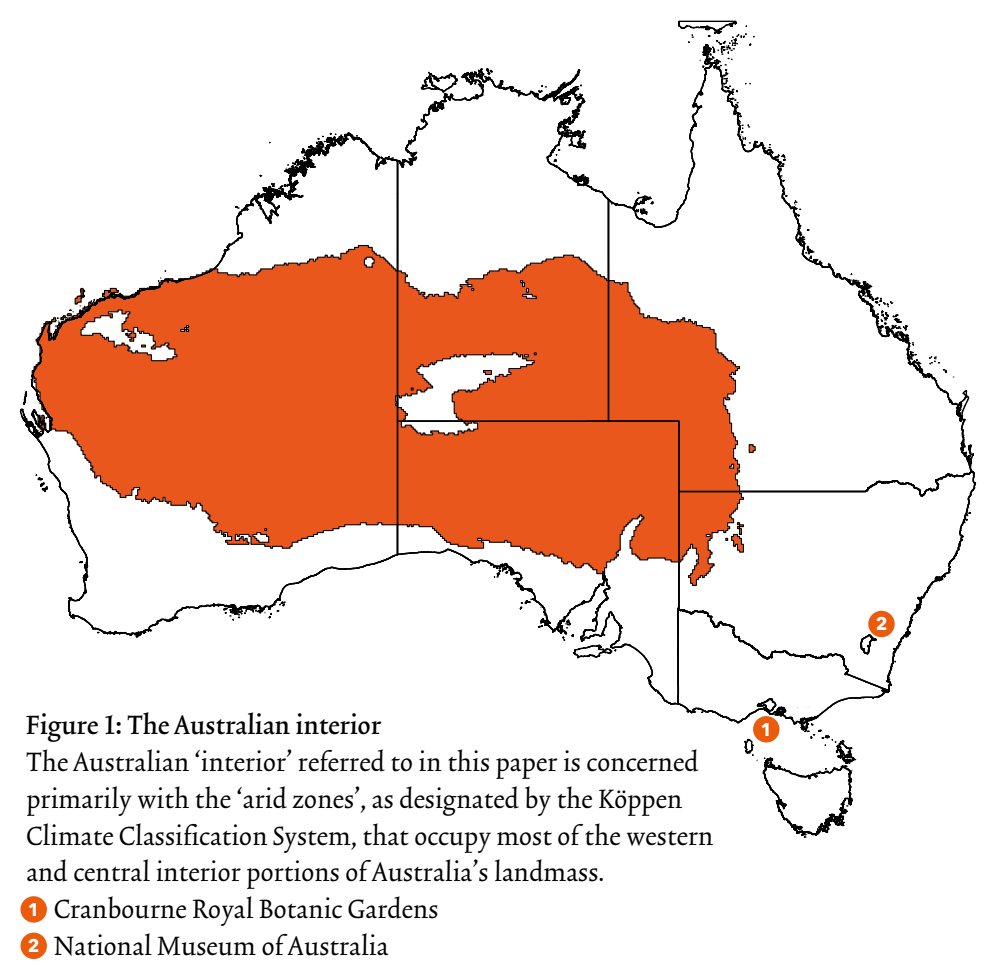



sity of Canberra, explained that European myths of the antipodes can be traced back to the Greeks, whose belief was based on the 'premise that the sphere is the perfect shape and that perfection demands balance' (Gibson 1992: 10). Thus they inferred that the overall landmass of the northern hemisphere must be balanced by a commensurate landmass in the south, garnished with similar resources to those of the north. As long as it remained an enigma, speculators were able to cast on to the 'Great South Land' all the 'characteristics of utopian yearning, vast resources of precious stone, timber, spices, all that Europe desired and valued' (Gibson 1992: 10). According to Veronica Brady, an Australian academic in history and literature, as a result of this long period of imagination, Australia is "primarily a country of the mind, in which physical realities are moulded by psychic factors, by the idea of the "Great South Land"' (Brady 1996: 9). That is to say, European Australians simultaneously occupy a physical 'Australia' as well as an inherited imagined 'Great South Land'. While this situation is not unique to Australia, for much of its European-Australian history the slippage between the imagined 'Great South Land' and the physical reality of Australia was substantial (Brady 1996: 9).

\section{National introspection}

The first European-Australian settlements tended to cluster on the coastal fringe of the continent (Gibson 1992: 9). From the point at which Australia's coastline had been surveyed in the early to mid-eighteenth century, the interior became the focus because it was still an enigma - and as such aroused speculation and to a lesser degree fear. It is instructive of European-Australian culture to identify the divergence between the settlement of Australia and North America. As Gibson explains:

There was never, in the myths of frontier America, the Australian sense of the forestalled reward, never a sense that the entire continent was cruelly tantalizing the settlers, simultaneously withholding and offering, drawing speculators inward to an imagined 'New Mediterranean', or a verdant central campaign (Gibson 1992: 12). In the colonization of North America, the inhabitation of the continent was a 'more open ended, liberating process. America had a constantly evolving frontier, with pioneers creating waves of ongoing westward settlement all the way from the East coast to California'. The westward push of the settlers was generally greeted with fertile land (Gibson 1992: 12).

Conversely, in Australia explorers yearned to discover an inland sea in the interior. They could not conceive that the arid plains they experienced on initial expeditions into the interior could extend across the entire continent. Explorer Charles Sturt's compulsion towards finding an inland sea in the 1840 resulted in him surveying arid regions ever closer to the very centre of Australia's landmass. These repeated disappointments that 'beset him slowly began to seem inevitable' (Gibson 1992: 15). In announcing his defeat, he recorded an insight that Gibson identifies as refashioning the theme of the 'forestalled reward' that was to be found at the centre of the continent: 'Men of undoubted perseverance and energy had in vain tried to work their way to that shrouded spot. A veil hung over central Australia that could never be pierced or raised ...' (Gibson 1992: 16).

\section{Enduring narratives of Australia's interior}

The interior as a site to be rendered useful

From such disappointments followed the European-Australian perspective of the interior as a barren wasteland that had to be 'improved' to have 'value' (French 2013: 5). As David Tacey, Professor of Literature at La Trobe University, explains: in this tradition the European-Australian settler 'converts the land into an image of an ego ideal. A utopian construct is formed which serves the ego's growth, meets its needs and reflects an image of peace and security' (Tacey 2009: 93). This conception of a settled and farmed interior was promoted by populist believers in 'Australia Unlimited', who in turn thought that the country could support 100 million people, or ideally more. To such believers the idea of accepting the aridity of the inland and leaving it empty was treasonous (Watson 2014: 218).

The zenith of this fervour was not the search for an inland sea, but the desire to actually create one. In 1933 Hungarian Joseph Holibal proposed a channel from Spencer's Gulf to Lake Eyre with this very aim in mind. In $1938 \mathrm{Dr}$ John Bradfield proposed a bold strategy to divert north Queensland rivers into the arid interior so as to make Lake Eyre a permanent water body. Bradfield proposed this vast body of water to alter the hydrological cycle, stimulating rain over areas hundreds of kilometres from Lake Eyre itself (Gillanders 2009: 40). The belief that these schemes embody - that 'land must be conquered, that land not useful to us is wasted' (Gillanders 2009: 42)-has been generally discredited, although such views still resurface periodically, as a recent proclamation from developer Harry 'high-rise' Triguboff indicates:

I'd like to see (a population of) one hundred million (in Australia), because I believe we will have many things to do here besides drilling holes and selling coal. Our agriculture has to be huge. Our desalination must be fantastic. Our rivers must flow the right way. It will all have to be developed (Australian Associated Press 2010).

\section{The interior as a site of sacrifice}

An alternative narrative of the interior emerged in the early twentieth century after the relative failure to transform the interior into something 'useful'. In this narrative the raw power of the landscapes of the interior 'strips' off the veneer of European-Australian civilization, to reveal something much more primal.

As has been discussed, the 'centripetal impetus' first set in motion by third-century-BC Greek myths of the 'Great South Land' had persuaded European explorers to predict that there was something remarkable to be found in Australia's interior. Once Charles Sturt's 1844 expedition to the centre of the continent confirmed there was no 'marvel in the material world, a revised version of the myth had to be formulated which would remain faithful to the belief in a plain of exaltation awaiting the utopian colonist' (Gibson 1992: 16). Gibson identifies this revised myth operating in Sturt's 1906 version of the veiled centre:

Once it is obvious that the paradise will not be found in the secular world, an alibi is required to explain away the failure. Almost inevitably the alibi is a tall tale, as if he is saying, what you will find out there is beyond classification or representation, beyond knowing, beyond imagining, and you will be sanctified if you test your secular life there and come to know its limitations (Gregory in Gibson 1992: 16). 
Gibson identifies this theme of defeated expectations of material 'rewards' and at the same time exaltation on a spiritual level as a prevailing undercurrent in Australia's colonial history (Gibson 1992: 17). Moreover, he identifies such myths of valiant failure as being needed by colonial society to reconcile with an intransigent continent-'the notion of sacrifice as a mythological ploy which excuses the implausibility of the quest to rectify the entire continent in terms of its submissiveness and bounty' (Gibson 1992: 89). David Tacey, in a similar vein, depicts explorers of the interior such as Sturt, Stuart, Leichhardt, Burke, and Wills as symbolically giving themselves to the archetypal interior that for the European settlers was a strong sign of 'otherness', the 'other' being that which was outside and threatening to the 'self (Tacey 2009: 102). In the case of Leichhardt, Burke, and Wills, this sacrifice was physical-these explorers died in the interior while on ill-fated expeditions. Such cases represented the transformation of 'spirit suspended arrogantly above the earth, to spirit suddenly crushed by earth and wedded to it' (Tacey 2009: 102). To Tacey's way of thinking, the personal sacrifice offered by each explorer to some degree satisfied the sacrificial tendencies of European Australians clustered together on the coast.

The interior as a site of authenticity

Given European Australia's failed attempts to subjugate Australia's interior-such as the Bradfield scheme to flood central Australia in the 1930s - this failure was 'explained away' from the mid-twentieth century onwards by the conceptualization and promotion of the interior as a site of Australian authenticity. In Australia's nationalist period, which developed during the lead-up to the Federation in 1901, 'the bush' was the 'womb and inspiration of the national character' (Watson 2014: 66). 'The bush' was seen as typically rural land between the 'outback' (the interior) and the beach and suburbia. In the Australian postmodern period, notionally from the early 1990s, the Nationalist repositories of authentic Australian-ness, the 'bush' and the 'working bushman', began to be supplanted by indigenous culture and symbols of the interior such as Uluru and Kala Tjuta weathered rock formations that 'visibly centre' the continent, in the minds of 'ordinary' Australians and international tourists. Evidence of the currency of this narrative is the promotion of Uluru and Kala Tjuta, in particular, as destinations for tourists to experience the 'real' Australia (Lee 2011: 99). As Richard Weller, designer of the Garden of Australian Dreams (one of the cases discussed here) explains, when even Australians decide to 'see Australia' they go looking for something authentically Australian, and frequently this is Uluru (Weller 2001: 84).

The following section of this paper will further explore a selection of these narratives through an analysis of two key Australian landscape architectural projects that seek to represent or reference Australia's interior, the Red Sand Garden at the Royal Botanic Gardens at Cranbourne, Melbourne (opened in 2006), and the Garden of Australian Dreams at the National Museum of Australia in Canberra (opened in 2001).

Landscape architecture and representations of the interior While the day-to-day practice of most Australian landscape architecture offices tends to be directed towards delivering projects in Australia's major cities, there are exceptions that are well covered in the existing literature.[2] Complementing this work is a parallel body of landscape architectural projects that are not located in the interior but in major cities on Australia's coasts, and that attempt to spatially represent the interior. Apart from the projects that are analyzed in this paper, other projects dating from the mid-199os are the Red Centre Garden at the National Botanic Gardens in Canberra, small domestic gardens such as the Red Garden in Sydney (by Vladimir Sitta) and a winning entry to the Chelsea Flower Show in 2011 called the Australian Garden (by Jim Fogarty), and a series of conceptual garden installations (by Taylor Cullity Lethlean). Reflecting on the tendency of these landscape architects to re-create the red landscapes of the interior in Australian cities, landscape architecture academic Kate Gamble had asked the question: 'That ubiquitous red sand-are we destined to endlessly replicate the colours of the arid centre ... ?' (Gamble 2014).

In the next section the meaning of this 'endless replication' of the interior in Australian landscape architecture is explored and charted in relation to the narratives of the interior discussed in the first part of this paper.

The cultural context

In 1995, the commission to design the Australian Garden at the Royal Botanic Gardens at Cranbourne was awarded to Taylor Cullity Lethlean (TCL) and in 1997 that of the Garden of Australian Dreams in Canberra to the (now defunct) landscape architecture practice, Room 4.1.3. (Ware 2013: 74). Both projects were awarded through a design competition process and specifically nominated as 'Australian gardens'. In that period the conservative Prime Minister of the time, John Howard, had been determined to stimulate discussion to define Australian identity. This wound up in what is colloquially referred to as 'the History Wars' (Ware 2013: 74), in essence being a public debate on interpretations of the British colonization of Australia. In particular deliberations have centred on the degree to which EuropeanAustralian culture made concentrated efforts to wipe out indigenous culture (Weller 2005: 241). The Red Sand Garden and the Garden of Australian Dreams can be understood as responses to both Australia's contested history and identity (Ware 2013: 74). In Richard Weller's terms such projects were 'focused moments' that 'apprise the nation's future as an historical project and which expect to cast such thinking into public space' (Weller 2001: 66).

\section{The Red Sand Garden at the Australian Garden at Cranbourne Royal Botanic Gardens}

Formal structure

The Royal Botanic Gardens in Cranbourne is a 25-hectare botanic garden located on Melbourne's south-east fringe, designed by Melbourne- and Adelaide-based landscape architecture firm TCL, and opened in 2006 (Fig. 3). At the geographic centre of the Australian Garden is the Red Sand Garden, which consists of a generous expanse of red earth animated with a scattering of (hemi-)circular plantings of desert spinifex, a ceramic low-lying Ephemeral Lakes sculpture that references the iconography of the salt pans (Russell-Clarke 2011: 105), a planted 'line' that represents the straight direction of the first European explorers when crossing the continent, and crescent-shaped landforms that are an interpretation of the landforms of Lake 


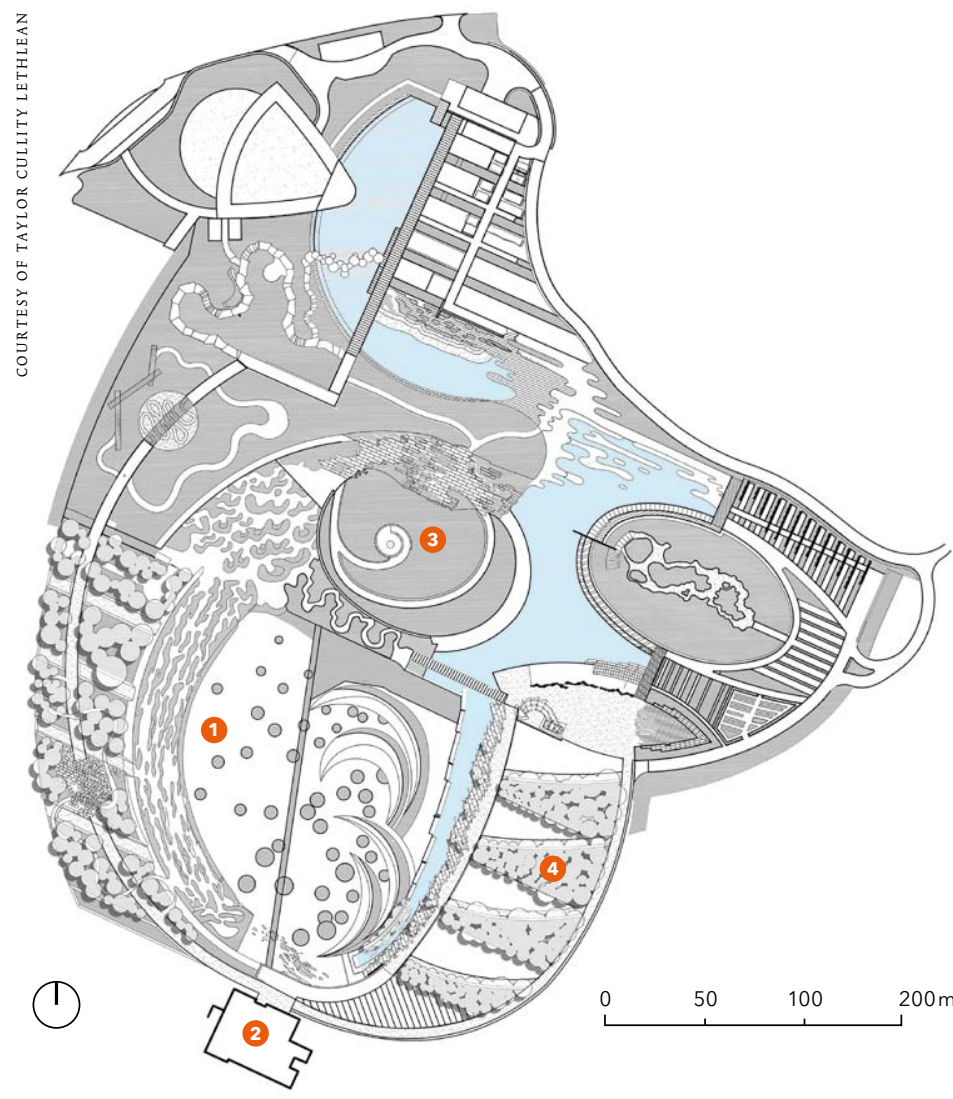

Mungo (Diedrich 2013: 14), a dry lake in the interior of New South Wales (Figs. 4 \& 5). Arranged around this red expanse are various smaller gardens including the Home Garden, the Future Garden, and the Kids Backyard. The formal structure of the Australian Garden essentially mimics a typically European-Australian conceptualization of the Australian continent with its domesticated and comparatively verdant edge fringing a largely uninhabited and barren centre, which is alien and afforded 'no public access ...' (Russell-Clarke 2011: 105).

The Red Sand Garden is typically viewed from the raised Visitor Centre at the entrance to the botanic garden and its upstairs café where viewers are, as Kate Gamble explains, 'centred and elevated ... positioned at the perfect angle for the colonizing gaze, surveying its conquered domain' (Fig. 6) (Gamble 2014). As visitors descend into the garden they receive partial views across the Red Sand Garden as they circle through the fringing smaller scale gardens. From the Gibson Hill lookout they are again awarded with another panorama across the Red Sand Garden.

TCL's design concept

The work of TCL can be broadly linked to the 'conceptualist' movement in landscape design (Richardson 2013: 48), in which form is generated within the inner resources or intuitions of the designer (Gelerntner 1996: 7). In this vein the Red Sand Garden is an abstraction of 'the interior' as it exists in the minds of its designers. This abstraction was formed through direct experiences of the landscapes of Australia's interior, abstract paintings of the interior by Australian artist Fred Williams, and TCL principal Perry Lethlean'swho studied karesansui-dry sand or rock gardens in Japan (Meyer 2013: 61). The complexity of 'representation' in the Red Sand Garden arises from the
Figure 3 Plan of the Royal Botanic Gardens in Cranbourne The 25-hectare botanic garden is located on Melbourne's south-east fringe.

(1) The Red Sand Garden

(2) Visitor Centre and entry

(3) Gibson Hill lookout

(4) Display gardens including the Home Garden, the Future Garden, and the Kids Backyard

fact that when this amalgamated image of the interior is brought into being in a site completely removed from the interior, such as south-eastern Melbourne, it conflicts with the existing landscapes of the site-landscape being a 'highly situated phenomenon, literally bound into geographical places and topographies' (Corner 1992: 247). Indeed, three existing lakes had to be filled in with sand in order to compose the artifice of the Red Sand Garden (Diedrich 2013: 14). In this respect the Red Sand Garden, although in formal terms very different, does reflect the process by which many eighteenthcentury, English picturesque landscapes were 'laid out as an arrangement and disposition of scenes' (Corner 1992: 260). It is about the creation of an image of a remote landscape that is in some respects contrary to the actual landscape in which the project is being realized.

\section{The narrative of sacrifice}

The Red Sand Garden attempts to evoke the sublime qualities-the awe, intensity, vastness—of Australia's interior (Curl 2006: 752). The sublime refers to the overpowering sense of nature devoid of human interference, which has the power to 'compel and destroy us' (Van der Velde and Hoedemakers 2015: 13). Through employing fractal geometry, suggesting a resemblance at small to large scales (Carter 2013: 179) in combination with an absence of people or trees, the Red Sand Garden can be readily imagined at a vast scale (Russell-Clarke 2011: 105). Through conjuring a sense of vastness of scale the garden aspires to distil the sublime qualities of the Australian interior and brings to mind humankind's insignificance in the face of nature. Moreover, the creation of an 'anti-garden' prohibits entry and as such 'resists an Eden-like return'. As Australian philosopher and writer Paul Carter explains: 
Figure 4 Aerial image of the Royal Botanic Gardens At the geographic centre of the Australian Garden is the iconic Red Sand Garden.

Figure 5 Aerial view of the Red Sand Garden looking towards the Visitor Centre

The Red Sand Garden consists of a generous expanse of red earth animated with a scattering of circular xerophytic plantings like desert spinifex; a ceramic prostrate Ephemeral Lakes sculpture that references the iconography of salt pans; a line of planting that symbolizes the straight direction of the first European explorers when crossing the continent; and crescentshaped landforms that are an interpretation of the landforms of Lake Mungo.

(1) Visitor Centre

(2) Red Sand Garden

3 Display gardens

(4) Crescent-shaped landforms

Figure 6 View of the Red Sand Garden from the Visitor Centre

Photographs of the Red Sand Garden towards Gibson Hill are typically taken from the Visitor Centre at the entrance to the botanic garden.

(1) Ephemeral Lakes sculpture

2 Circular xerophytic plantings

(3) Line of prostrate planting
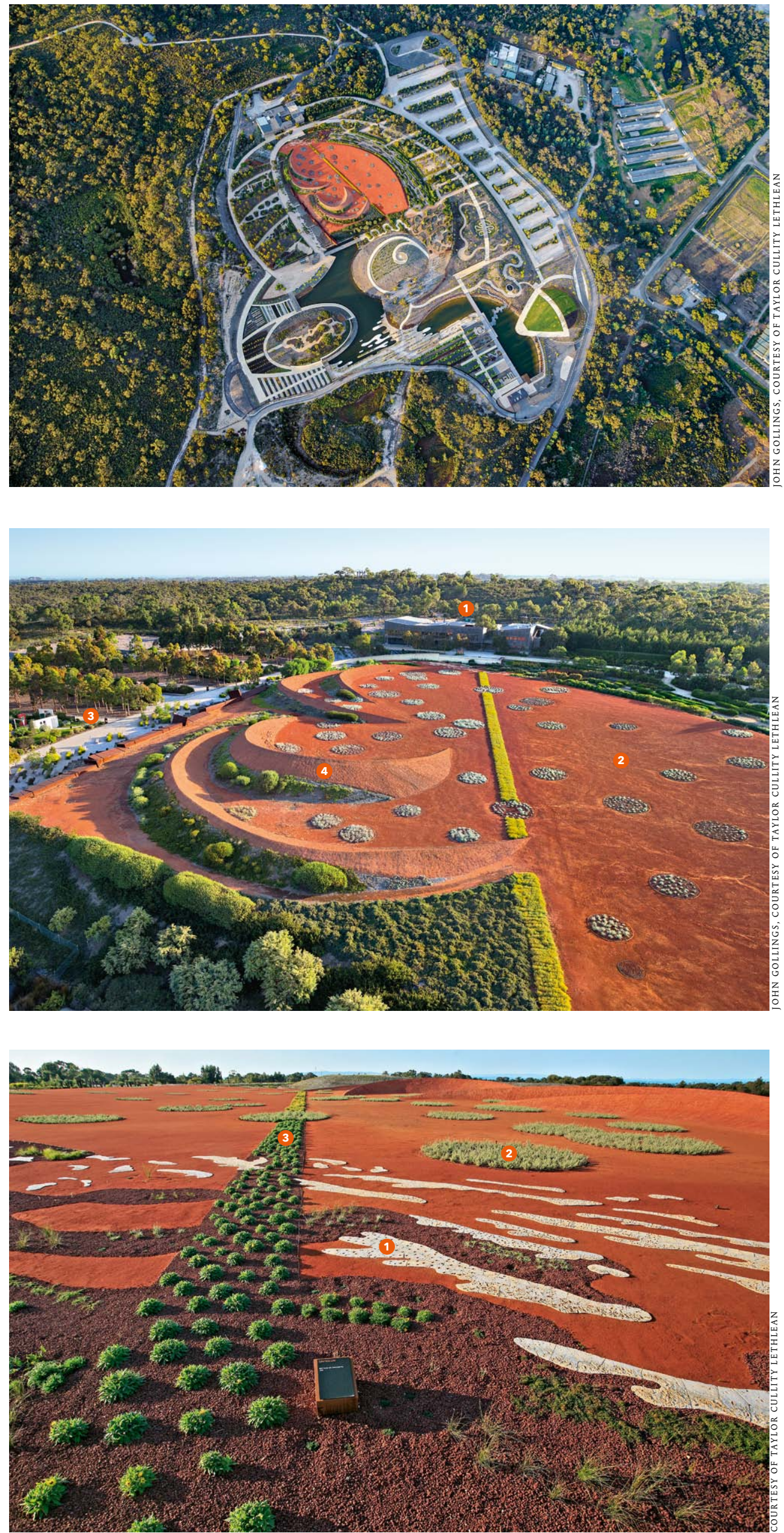


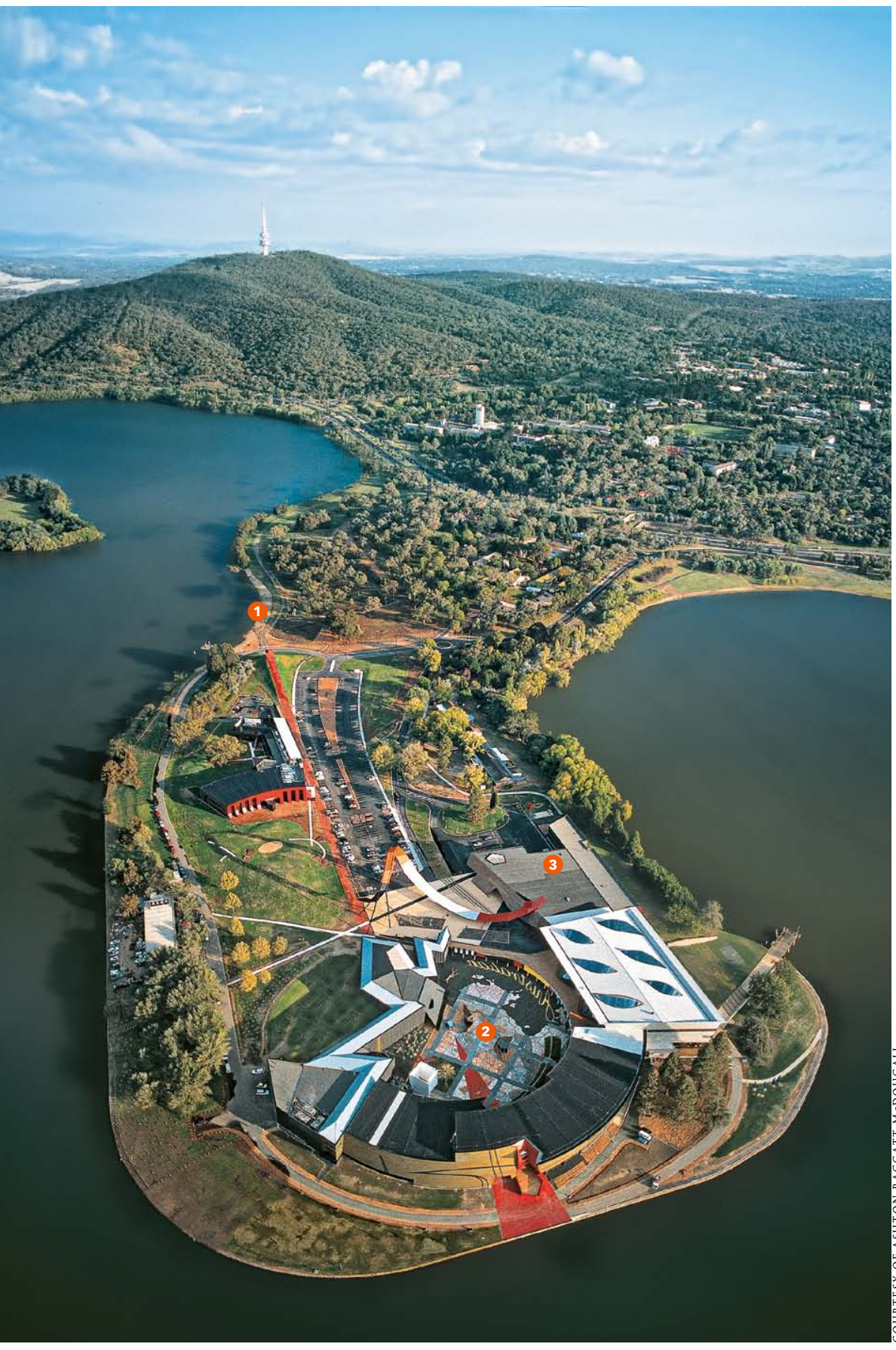

Figure 7 The National Museum

The main landscape architectural features of the National Museum include the Uluru Line and the Garden of Australian Dreams.

(1) Uluru Line

2 The Garden of Australian Dreams

(3) Museum entry hall

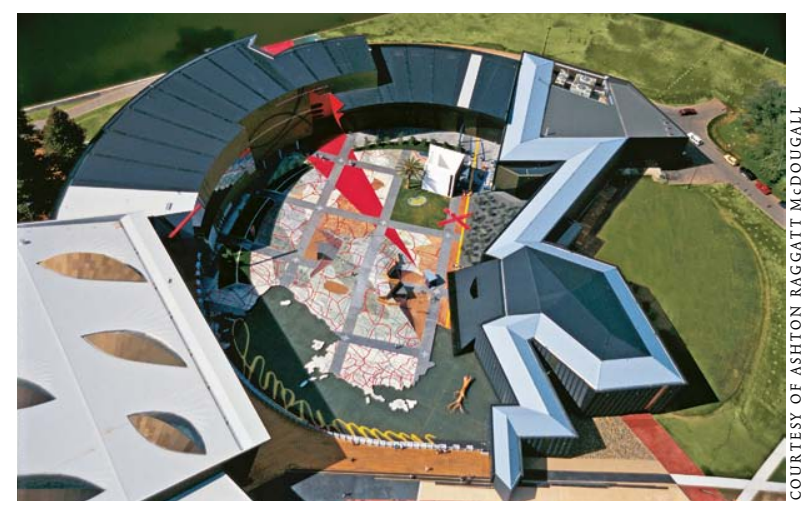

Figure 8 The Garden of Australian Dreams

The Garden framed by the National Museum of Australia buildings

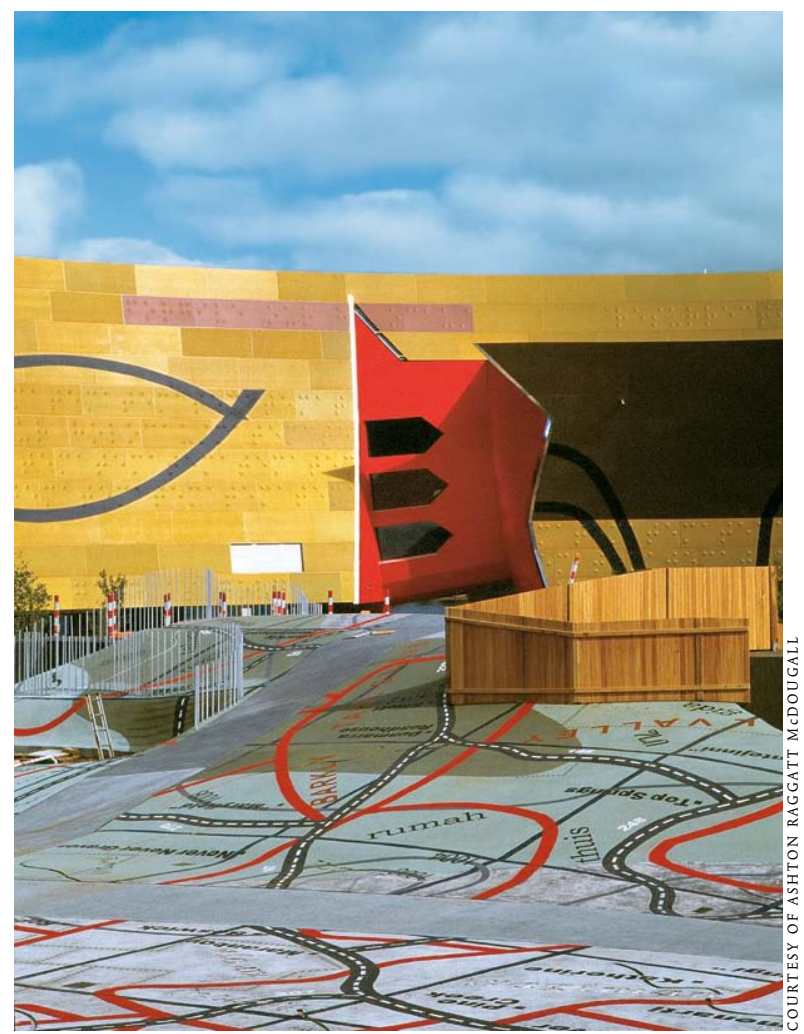

Figure 9 The Garden of Australian Dreams

The Garden of Australian Dreams is largely a concrete surface that gently undulates, although to a significant height at one point, and across which text and markings flow. The text and markings are principally a palimpsest of two maps of Australia: an English-language map and David Horton's map of indigenous linguistic boundaries. 
... instead of providing functional paths and achievable destinations, the design introduces resistances that bring home to the visitor the strangeness of their condition. The possibility is raised that certain parts of the Earth shall not be visited, that something remains inaccessible (Carter 2013: 178).

The notion of inaccessibility has strong thematic links to the experience of European-Australian colonization in which there was a 'sense of the forestalled reward ... a sense that the entire continent was cruelly tantalizing the settlers, simultaneously withholding and offering ...' (Gibson 1992: 12). Furthermore, the concept of the unoccupiable garden suggests a dualistic situation in which man is separate from the world he inhabits (Gelerntner 1996: 27). In the Australian context this reflects a situation in which, for most European Australians, the bush and by extension the interior 'exists outside of us, is for our use' and 'yet contains only that which we can see' (Watson 2014: 87). In other words, while colonial culture may have subjugated the land in physical terms, the spirit of the land remains elusive, a 'spirit from which the colonizing culture is estranged' (Tacey 2009: 116). Through its inaccessible nature the Red Sand Garden evokes a sense of estrangement from a deeper understanding of 'place', which is revealing of European-Australian culture's ongoing alienation from the interior.

The narrative of authenticity

Contemporary botanic gardens like the Royal Botanic Gardens are institutions for research and education as well as entertainment. Their missions have moved beyond nineteenth-century scientific aspirations to 'collect, catalogue and curate' (Meyer 2013: 60). In one sense the Australian Garden operates as a theme park of Australian landscapes (Saniga 2012: 295). As part of this, the Red Sand Garden serves up an abstracted, miniaturized image of Australia's vast interior, even if it does not deliver the full 'sensorium of the tactile, the poetries of material and touch' (Corner 1992: 249) that the 'real' interior offers.

Catherin Bull, Professor of Landscape Architecture at the University of Melbourne, explains that a proliferation of photographic imagery has 'popularised the landscapes of Australia's interior and made them part of the mental map of Australia' (Bull 2002: 39). The Red Sand Garden feeds a similar dynamic by dishing up dramatic photo opportunities across its red expanse (Fig. 6). In this sense the garden trades on the narrative of 'authenticity'. The visitor experiences the interior landscape, abstracted into a 'foreign' context on the outskirts of Melbourne-the signature of the project being red sand that is not actually from the interior. Such is the 'fabulously reproducible' imagery of the Red Sand Garden, explains Kate Gamble, that 'if we consider the Australian Garden, it's impossible not to think of the red sand, of that image of the red sand. It is so striking-a remarkably effective logo for the project...' (Gamble 2014). In the context of a deepening divide and disconnection between city and country (Bunbury 2015: 188), and a world of Internet image searches, the Red Sand Garden becomes almost interchangeable with that of real arid landscapes of the interior.
The Garden of Australian Dreams at the National Museum of Australia in Canberra

Formal structure

The Garden of Australian Dreams (opened in 2001) was designed for the central courtyard of the National Museum of Australia. To contribute to Australia's identity and education the museum was sited adjacent to Canberra's ceremonial precinct, the end of Acton Peninsula, which juts out into Lake Burley Griffin. The museum itself embodies a roughly circular collection of buildings designed by Melbourne architecture firm Ashton Raggatt McDougall (ARM). These buildings are 'wrapped' around the central Garden of Australian Dreams (Ware 2011: 45) and ordered by the Uluru Line, the main landscape architectural features of the national museum. Both elements were designed by Richard Weller and Vladimir Sitta, the former directors of the now defunct landscape architecture practice Room 4.1.3 (Figs. $7 \& 8$ ).

The Garden of Australian Dreams itself consists of a concrete surface which gently undulates and across which text and markings flow (Fig. 9) (Raxworthy 2005: 175). These graphics were drawn from two maps of Australia-an English-language map of Australia and David Horton's map of indigenous linguistic boundaries. Other layers that are present include maps of vegetation, soil and geology, electoral boundaries, Australia's history of exploration, and oddities such as weather systems taken from Australia Day 1998 and a Japanese tourist map (Weller 2005: 218).

Visitors first overlook the garden from a higher level prior to entering the museum 'hall'. After proceeding through the hall, visitors can descend to a lower level where they can access the garden. For a number of reasons the initial experience of the garden is puzzling. Given that it is referred to as a garden, most people expect a 'bucolic, pacified nature' (Weller 2001: 73). The Garden of Australian Dreams however, eschews substantial planting-something that has been a source of considerable controversy. Also, depending on the visitor's perspective, the surface of the Garden of Australian Dreams is either a 'richly patterned and written concrete surface, made to look like folded paper or printed fabric' (Weller 2005: 218) or 'a weird 1970s external geography lesson' (Raxworthy 2005: 175). In both cases the garden feels alien-a space seemingly without a precedent.

The Uluru Line forms a red-tinted 300-m-long concrete strip that extends from the museum before curling skywards as it leaves the site (Fig. 10). As the name implies the axis is aligned with Uluru, the stone monolith located in Australia's arid interior. The Uluru Line is first experienced by visitors to the museum as they enter the museum's car park by car, forming a signature for the development.

Room 4.1.3's design concept

The use of Australia's interior as a motif or design generator can be found in a number of Room 4.1.3's unbuilt design competition entries from the late 1990s (Weller 2005: 190). The themes of the interior as absence and oblivion were to find their most dramatic expression in the collaboration between Room 4.1.3 and ARM for the National Museum of Australia. ARM and Richard Weller have collaborated closely on a number of projects and this approach has been extended into the landscape architectural design of the national museum. 
Owing to its eclectic and encoded design language, the museum and its garden can be firmly located within the postmodern period in which designers collected fragments of historical architectural and artistic movements (Gelerntner 1996: 279). [3] Whereas architects and landscape architects in the modernist period 'had tried artificially to impose order', the Garden of Australian Dreams, in particular, expresses a much more 'chaotic existential reality' (Gelerntner 1996: 286). This is achieved through the deployment of postmodern design operations such as 'layering, collage, superimposition, blurring, scaling, tracing, and at every stage abstracting', which produces moments of frisson and tension between the various map layers (Raxworthy 2005: 175).

The narrative of sacrifice

In his original City Beautiful-inspired plan from 1911 for Canberra, Walter Burley Griffin structured the city by deploying numerous axes emanating from the federal parliament towards far-flung state capitals and local landscape features. The design for the National Museum project forged a new axis onto Canberra's existing urban diagram by introducing a 'linear, curling, ribbon-like red structure' that connects Parliament House with Uluru (Ware 2011: 45). In this respect, the design for the National Museum 'forges an allegorical connection' to Australia's interior and 'leads the imagination along well-trodden historic and contemporary quests to find the heart and soul of Australia' (Weller 2001: 75). The re-wiring of Canberra's City Beautiful structure-through which its proponents believed restless populations could be 'civilized'-is a radical act. The weaving of the Uluru Line into the National Museum (where the axis is tied into a knot and registers as a subtraction from the building's massing) speaks to the idea of the interior as a site of destabilization of European-Australian culture. As Richard Weller explains 'it is well known and well documented that the Australian landscape mocks settlement and quietly destroys those who break its rules' (Weller 2001: 68). The axial connection between Parliament House and Uluru sets up a deliberately dualistic structure in which:

Canberra is culture and the desert is nature. Canberra is monumental architecture and the desert is monumental geology. Canberra is political centre and Uluru political periphery. Canberra is constitutional monarchy and the desert is aboriginal law. Canberra is reason and the desert is mysticism. Canberra is picturesque and the desert is sublime (Weller 2001: 75).

Along the Uluru Line the architecture of the National Museum of Australia channels the disquieting and alien qualities of the interior (Tacey 2009: 60) into the superstructure that orders Canberra's public edificesand serves as a reminder of how unsettled, in both senses of the word, Australia remains from a European-Australian perspective (Fig. 11).

Australia's interior is also evoked by the spatial qualities of the Garden of Australian Dreams. Catherin Bull explains that the garden employs a combination of 'formal references' to lend a 'surreal' aesthetic quality to a space that she believes is 'perhaps a more helpful lens than the picturesque through which to conceptualize the vast emptiness of the Aus- tralian landscape' (Bull 2002: 145). The garden's layering of maps is critical to creating the 'surreal' qualities that Bull identifies. In the initial European colonization of Australia there could be no law unless its jurisdiction was mapped (Watson 2014: 278). To bring the continent under British rule, law maps needed to be made to inventory the geographical features of the land and its owners. These maps performed the 'essential legal-and probably psychological—function of filling in the savage emptiness' (Watson 2014: 278). By collaging and distorting these maps and adding David Horton's map of indigenous linguistic boundaries, the Garden of Australian Dreams depicts Australia as the "most contested of symbolic terrains ...', alluding to unresolved land claims by indigenous Australians (Weller 2005: 218). Rather than delivering a soliloquy about a 'sense of place', the Garden of Australian Dreams agitates for, and achieves, a confronting 'sense of placeless-ness' (Gelerntner 1996: 286).

\section{Conclusion}

Despite over 200 years of European settlement of the Australian continent, the interior continues to serve as a reminder that the Western ego is 'not authentic, and its former pretence at belonging is no longer adequate' (Tacey 2009: 100). This realization has led to the narratives that the case study projects analyzed here perpetuate. First, that the interior, in all its vast sublimity, mystery, and 'otherness', is a site of destabilization or even sacrifice for European-Australian society. In this way of thinking, 'European Australia has denied the true spirit of the land, and its indigenous inhabitants, for two hundred years of white settlement, and now the repressed is coming back to haunt us' (Tacey 2009: 99). Secondly, that the interior is a repository of what is authentic about Australia.

Given this situation, should these narratives be perpetuated by landscape architectural projects? In a word, we would argue, yes. While the case study projects are cultural creations that can be read as 'symbolic pointers to what is taking place in the psyche' of European-Australian society (Tacey 2009: 77), by virtue of their public, symbolic and controversial nature, they question how European-Australian culture relates to the landscapes of Australia's interior, and by extension indigenous culture. In the reading offered by this paper they are openly reflective of the unmanageable and, to a large degree, unknowable nature of the Australian continent, which continues to deny the premise of European Australia's settlement and control.

The importance of both these projects is that they serve as a humbling reminder of this situation. The presumption being that being free from a colonial mentality, in which the landscapes of Australia's interior are either considered to be requiring of improvement or marketing, may give birth to a deeper, more meaningful relationship with Australia's interior and indigenous people. The projects studied raise important questions, but offer no easy answers. They do, however, through a humbling process open the doors for a new form of consciousness to emerge. 


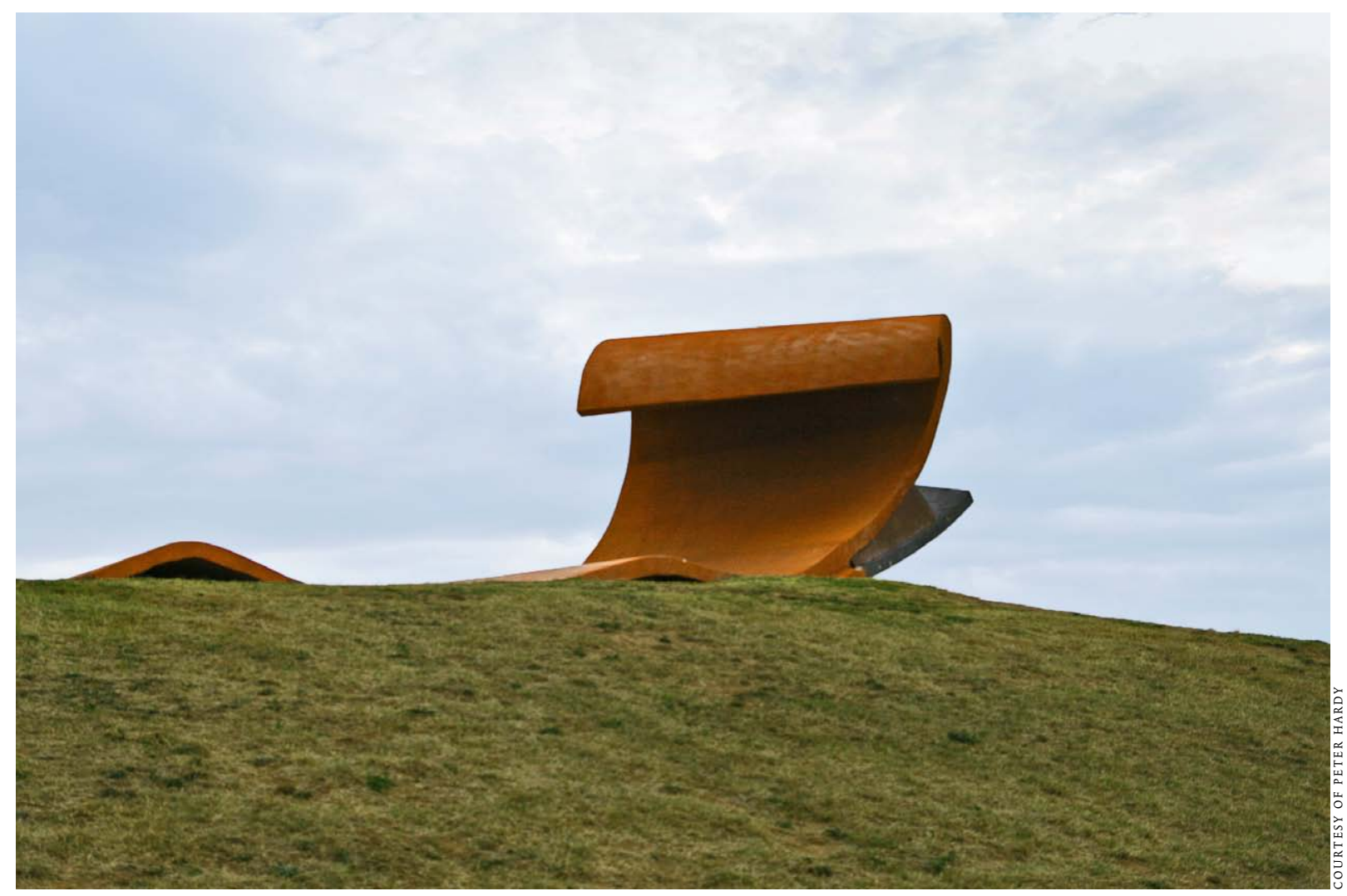

Figure 10 Uluru Line

The Uluru Line forms a red-tinted 300-m-long concrete strip that extends from the museum before curling skywards as it leaves the site.

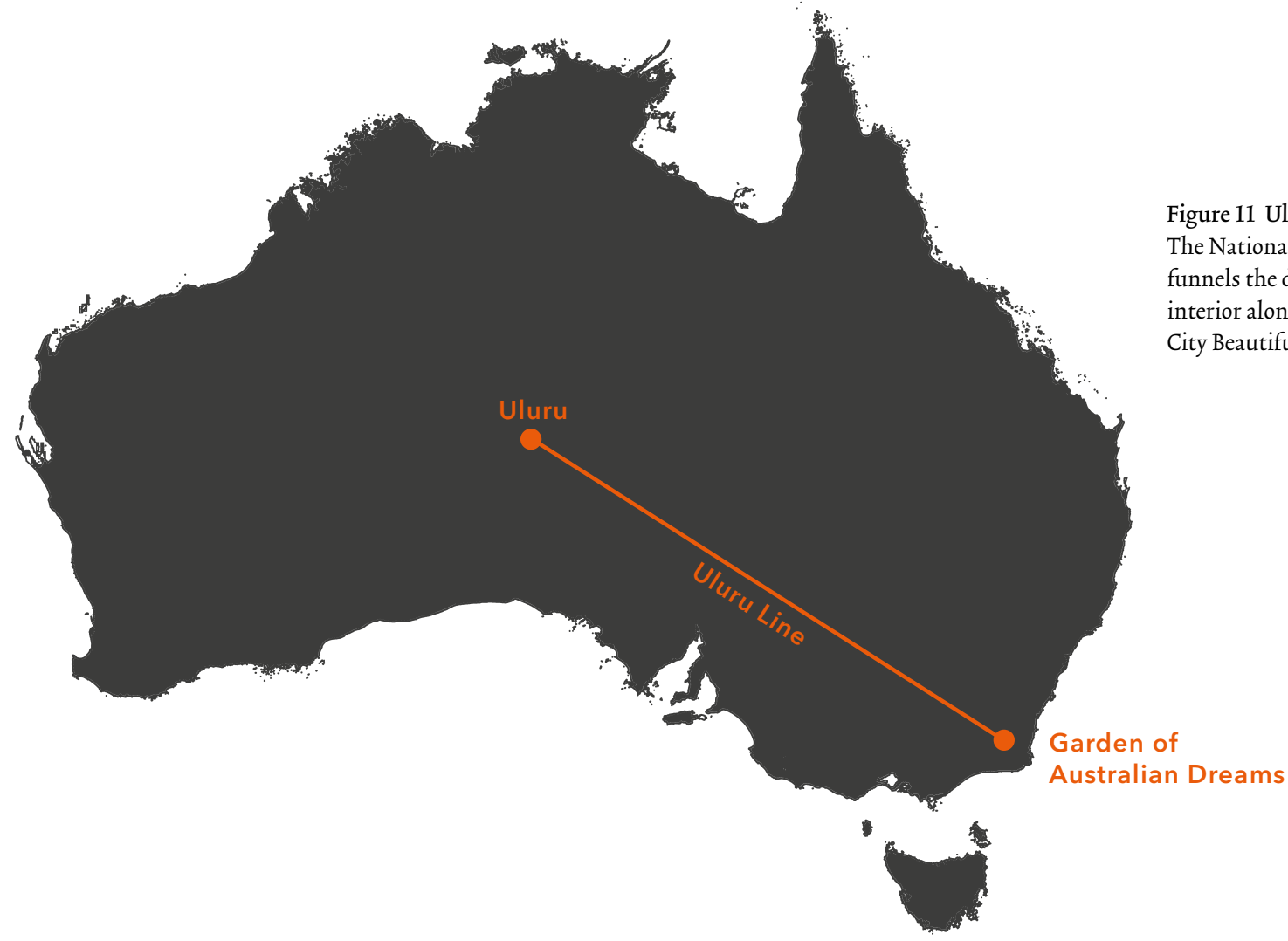


Implications for Australian landscape architecture

The implications of the case study projects are twofold. First, they openly refer to their own estrangement from the landscapes of the interior, a situation that can be generalized to the discipline of landscape architecture in Australia. Taylor Cullity Lethlean's principal Kevin Taylor explains this emerging realization of 'not knowing' the interior as a 'grieving process' that constitutes a sequence of phases including denial, acceptance and, finally, reorganization:

Shock, denial

Protest, anger, guilt, sadness, fear

Disorganization, despair, apathy, anxiety, confusion

Reorganization, changed values, new meaning

This period has social, cultural, political and spiritual dimensions

(Lee and Ware 2013:4).

Moreover, Taylor exhorts that the overarching challenge for landscape architecture in Australia, in the coming decades, will be to grapple with this process directly and productively (Lee and Ware 2013:4).

So what is the implication of this 'not knowing' Australia's interior for the profession of landscape architecture, particularly given that it is likely that the vast bulk of landscape architectural projects will continue to be found in the big cities and not in the interior? European Australia's 'not knowing' would suggest that the discipline of landscape architecture could benefit from a deeper engagement with indigenous culture that, as David Tacey reminds us, holds 'the keys to the spirit of the land', a spirit from which the colonizing culture-by virtue of this Australian landscape architecture-is typically estranged (Tacey 2009: 116). This situation has significant pitfalls from an environmental perspective:

We can muster all the good intentions and moral correctness that we can find, but unless we discover some deeper, transformative relationship with place our good intentions will be in vain and we will only be half-hearted about reconciliation and ecological matters (Tacey 2009: 204).

This is not to say that landscape architects are not delivering positive environmental outcomes in Australia, just that deepening connections with landscape will likely also deepen contributions to the environment and cross-cultural reconciliation. Neither the Garden of Australian Dreams nor the Red Sand Garden dictate what this 'deeper, transformative relationship with place' would look like. However, they do serve as effective reminders of our estrangement from the land, and by extension the need for landscape architecture to forge a deeper connection with indigenous custodians of land. This need is not new, yet there are numerous ways in which it could be tackled by the profession. One possibility is to increase the number of practising indigenous landscape architects so that indigenous people are not just 'consulted', but actually embedded in and directing design processes and to a degree the profession itself.
Finally, the Red Sand Garden and the Garden of Australian Dreams remind the profession of landscape architecture in Australia that projects do not need to be just a passive container of culture. Both projects illustrate that landscape design can be used to provoke culture and its ways of relation to landscape. This thinking was embodied by a rash of projects conceived in the lead-up to the millennium, but has been largely absent in Australian landscape architectural projects since then. While it may not always be popular, as the criticisms of both the Red Sand Garden and the Garden of Australian Dreams indicate (Gamble 2014; Weller 2005: 240), landscape architecture as a means to communicate conceptual ideas can shift culture rather than merely represent it. One way is to characterize landscape architecture as a 'passive' discipline (Weller 2006: 67) that generally produces 'natural conditions' (Edquist 1994: 43), implying that particular cultural norms cannot be changed. Counter to this tendency, the case study projects reviewed here, in part through their reference to the Australian interior, seek to unsettle current cultural norms in the hope that out of destabilization new norms can emerge. 


\section{ACKNOWLEDGEMENTS}

Thanks to Richard Weller who supervised the research which formed the first section one of this paper. Thanks to Taylor Cullity Lethlean and Ashton Raggatt McDougall for providing imagery. Finally, thanks to the reviewers of earlier drafts of this paper for their constructive and insightful comments.

\section{NOTES}

1 For example Bull 2002, Lee 2011, Mossop 2006, Saniga 2012, and Sinatra and Murphy 1997.

2 For example Bull 2002 and Mossop 2006.

3 Examples for the National Museum included Daniel Libeskind's Jewish Museum in Berlin, Le Corbusier's Villa Savoye, and Jackson Pollock's painting Blue Poles (Gelernter 1996: 286).

\section{REFERENCES}

Australian Associated Press, 'Population to hit $55 \mathrm{~m}$ by 2050: Triguboff [website], www.smh.com.au//breakingnews-national/population-to-hit-55m-by-2050-triguboff20100125-mt45.html, accessed 18 November 2015.

Blackwell, M. (2011), 'Understanding the Resource of Our Landscapes', Australian Garden History 23/1: 5-8.

Brady, V. (1996), Can These Bones Live (Leichhardt, NSW: The Federation Press).

Bull, C. (2002), New Conversations with an Old Landscape: Landscape Architecture in Contemporary Australia (Mulgrave, VIC: The Images Publishing Group).

Bunbury, B. (2015), Invisible Country: South-West Australia: Understanding a Landscape (Perth: University of Western Australia Publishing).

Carter, P. (2013), 'For Kevin', in G. Lee and S. Ware (eds.), Taylor Cullity Lethlean: Making Sense of Landscape (Washington, DC: Spacemaker Press), 176-180.

Corner, J. (1992), 'Representation and Landscape: Drawing and Making in the Landscape Medium', Word \& Image 8/3: 243-275.

Commonwealth Scientific and Industrial Research Organization (CSIRO), 'Welcome to OzClim: Exploring Climate Change Scenarios for Australia' [website], www.climatechangeinaustralia.gov.au/en/, accessed 18 November 2015.

Cullity, K. (2013), 'Material Presence', in G. Lee and S. Ware (eds.), Taylor Cullity Lethlean: Making Sense of Landscape (Washington, DC: Spacemaker Press) ,54-110.

Curl, J. (2006), Oxford Dictionary of Architecture and Landscape Architecture (Oxford: Oxford University Press).

Diedrich, L. (2013), 'As Seen from Europe', in G. Lee and S. Ware (eds.), Taylor Cullity Lethlean: Making Sense of Landscape (Washington, DC: Spacemaker Press).
Edquist, H. (1994), 'Culture and the Landscape of Colonization', in H. Edquist and V. Bird (eds.), The Culture of Landscape Architecture (Melbourne: EDGE Publishing Committee), 43-52.

French, J. (2013), Let the Land Speak: A History of Australia: How the Land Created Our Nation (Sydney: HarperCollinsPublishers).

Gamble, K. (2015), 'The Australian Garden' [website], http://architectureau.com/articles/the-australian-garden/, accessed 21 January 2016.

Gelerntner, M. (1996), Sources of Architectural Form: A Critical History of Western Design Theory (Manchester: Manchester University Press).

Gibson, R. (1992), South of the West

(Indianapolis: Indiana University Press).

Gillanders, A. (2009), 'Mirage of the Inland Sea: The Bradfield Scheme', Journal of the Royal Australian Historical Society 95/1: 38-51.

Lee, G. (2011), 'Uluru-Kata Tjuta Cultural Centre', in S. Ware and J. Raxworthy (eds.), Sunburnt: Landscape Architecture in Australia (Amsterdam: SUN), 98-103.

Lee, G. and Ware, S. (2013), Taylor Cullity Lethlean: Making Sense of Landscape (Washington, DC: Spacemaker Press).

Meyer, E. (2013), 'Grafting, Splicing and Hybridising: The Strange Beauties of the Australian Garden, Cranbourne', in G. Lee and S. Ware (eds.), Taylor Cullity Lethlean: Making Sense of Landscape (Washington, DC: Spacemaker Press), 56-69.

Mossop, E. (2006), Contemporary Australian Landscape Design (Sydney: BT Latitude).

Pardoe, C (2006), 'Becoming Australian: Evolutionary Processes and Biological Variation from Ancient to Modern Times', Before Farming 1: 1-21.

Raxworthy, J. (2005), 'Room 4.1.3 and Australian Landscape Architecture', in R. Weller (ed.), Room 4.1.3: Innovations in Landscape Architecture (Philadelphia: University of Pennsylvania Press), 172-177.

Richardson, T. (2013), 'Festival Gardens as Laboratory of Ideas', in G. Lee and S. Ware (eds.), Taylor Cullity Lethlean: Making Sense of Landscape (Washington, DC: Spacemaker Press), 46-53.

Russell-Clarke, J. (2011), 'The Australian Garden, Cranbourne Botanic Gardens', in S. Ware and J. Raxworthy (eds.), Sunburnt: Landscape Architecture in Australia (Amsterdam: SUN), 104-113.

Saniga, A. (2012), Making Landscape Architecture in Australia (Sydney: NewSouth Publishing).

Sinatra, J. and Murphy, P. (1997), Landscape for HealthSettlement Planning and Development for Better Health in Rural and Remote Indigenous Australia (Melbourne: RMIT University).

Swaffield, S. and Deming, E. (2010), Landscape Architecture Research (Hoboken, NJ: Wiley).
Tacey, D. (1995), Edge of the Sacred: Transformation in Australia (Melbourne: Harper Collins).

Tacey, D. (2009), Edge of the Sacred: Jung, Psyche, Earth (Einsiedeln, Switzerland: Daimon Verlag).

Trewin, B. (2015), '1301.0-Year Book Australia, 2006' [website], www.abs.gov.au/ausstats/abs@.nsf/Previousproducts/1301.0Feature\%20Article22006?open, accessed 16 November 2015

Van der Velde, J. R. T. and Hoedemakers, V. (2015), 'The Wilderness Within', in Uje Lee (ed.), Strootman: Strategies for the Sublime (Seoul: C3 Publishing Co), 6-15.

Ware, S. (2011), 'Garden of Australian Dreams', in S. Ware and J. Raxworthy (eds.), Sunburnt: Landscape Architecture in Australia (Amsterdam: SUN), 44-46.

Ware, S. (2013), 'Site Thinking: The Completion of the Australian Garden at Cranbourne', in G. Lee and S. Ware (eds.), Taylor Cullity Lethlean: Making Sense of Landscape (Washington, DC: Spacemaker Press).

Watson, D. (2014), The Bush: Travels in the heart of Australia (Melbourne: Penguin/Hamish Hamilton).

Weller, R. (2001), 'The National Museum, Canberra, and Its Garden of Australian Dreams', Studies in the History of Gardens $\mathcal{E}$ Designed Landscapes 21/1: 66-84.

Weller, R. (2005), Room 4.1.3: Innovations in Landscape Architecture (Philadelphia: University of Pennsylvania Press).

Weller, R. (2006), 'Global Theory, Local Practice’, Kerb 15: 66-71.

\section{BIOGRAPHICAL NOTES}

Julian Bolleter is an assistant professor at the Australian Urban Design Research Centre at the University of Western Australia, where he teaches a Master's programme in urban design and conducts research and design projects. He is a landscape architect and urban designer and has worked in Australia, the United States, the United Kingdom and the Middle East. He completed a $\mathrm{PhD}$ on landscape architectural practice in Dubai and has published three books: Made in Australia: The Future of Australian Cities (with Richard Weller), Take Me to the River: A History of Perth's Foreshore and Scavenging the Suburbs.

\section{CONTACT}

Julian Bolleter

The Australian Urban Design Research Centre

University of Western Australia

Level 2

1002 Hay Street

Perth, WA 6000, Australia

Phone: +61863186203

Julian.bolleter@uwa.edu.au 